\section{Entre la reorganización y la derrota. El peronismo bonaerense en vísperas de las elecciones de 1983}

Marcela P. Ferrari
Marcela P. Ferrari es Investigadora del CONICET, Profesora del Departamento de Historia y miembro del Centro de Estudios Históricos de la Facultad de Humanidades, Universidad Nacional de Mar del Plata.

e-mail:mferrari@mdp.edu.ar

\section{Resumen}

El artículo indaga el modo en que el Partido Justicialista de la provincia de Buenos Aires enfrentó su reorganización una vez producida la última transición hacia la democracia, entre la apertura política de julio de 1982 y las elecciones generales de octubre de 1983. Luego de señalar las divisiones internas que afectaban al peronismo bonaerense, se observa el proceso de reorganización en torno a tres cuestiones: la afiliación y el empadronamiento; los enfrentamientos entre la justicia federal electoral, la provincial y la conducción partidaria; y las elecciones internas, que incluyeron reformas de las reglas que regulaban la vida del PJ. A partir de ello se interpreta la elección del candidato a gobernador, Herminio Iglesias, como la posible en un partido de base sindical, cuyos elementos de izquierda habían sido diezmados por la represión de la última dictadura y que no tenía una alternativa renovadora consolidada.

\section{Summary}

The article investigates the way in which the Justicialista Party of the province of Buenos Aires faced its reorganization once produced the last transition towards the democracy, among the political opening of July, 1982 and the general elections of October, 1983. After indicating the internal divisions that were concerning the Buenos Aires Peronism, the process of reorganization is observed around three questions: the affiliation and the census; the clashes between the federal electoral justice, the provincial one and the party conduction; and the internal elections, which included reforms of the rules that were regulating the life of the PJ. Starting from it the election of the candidate for governor, Herminio Iglesias, is interpreted as the possible one in a party of syndical base, whose left wing had been decimated by the repression of the last dictatorship and which did not have a consolidated renovating alternative. 